\title{
Clinical Study of Uses of a Small-volume Twin-coil Artificial Kidney (Chron-a-coil) in Acute Renal Failure
}

\author{
C. T. FLYNN,* M.R.C.P. ; C. H. BOWDEN, † B.SC., PH.D.
}

Brit. med. F., 1966, 2, 1109-1111

This paper describes our experiences in acute renal failure with the Chron-a-coil, a smaller version of the Kolff twin-coil artificial kidney. The Kolff twin-coil has been the most widely used artificial kidney in the treatment of acute renal failure (Merrill, 1963). The first report in this country was given by Jackson et al. (1960) from this unit. The twin-coil is supplied ready for use and is disposable; so that technical aspects are reduced to a minimum. It is capable of removing fluid by ultrafiltration, has a high efficiency, and is simple to use. These advantages are offset to some extent by the relatively high cost ${ }^{1}$ and the fact that 1 litre of blood is used in priming. Nevertheless, the benefits of haemodialysis outweigh these considerations, particularly if the need for dialysis is infrequent. However, since the work of Teschan et al. (1960) we have tended to dialyse more frequently, particularly in traumatic and postsurgical cases, in the belief that an improved clinical state is a justifiable aim in itself and also contributes to a lower mortality rate. The blood requirements and cost of such prophylactic dialyses does become a matter for concern.

Another occasional disadvantage of the standard twin-coil is a consequence of its efficiency. Too rapid eorrection of extracellular fluid abnormalities in patients who are grossly uraemic and acidotic may cause serious neurological and cardiovascular disorders, the so-called dialysis disequilibrium syndrome (Cowie et al., 1962 ; Kennedy et al., 1962). For such patients an artificial kidney with less efficiency is desirable.

It was with these considerations in mind that we decided to investigate the potential usefulness in acute renal failure of a smallvolume twin-coil (Chron-a-coil) which has been designed for use in the repeated dialysis of patients with chronic renal failure. We were influenced in our choice by the fact that the Chron-acoil is manufactured to fit the apparatus used with the standard twin-coil so that new equipment and techniques would not be required. So far we have done 120 Chron-a-coil dialyses in the treatment of 30 patients. The patients comprised 24 males and 6 females aged from 10 months to 67 years. They covered a broad aetiological spectrum, including trauma, burns, surgery, nephrotoxins, haemolysis, septicaemia, dehydration, and obstetrical complications. Eighteen patients had acute renal failure

- Squadron Leader, R.A.F. Renal Unit, Princess Mary's R.A.F. Hospltal, Halton, Aylesbury, Bucks.

† Principal Scientific Officer, Rcsearch Department, Institute of Pathology and Tropical Medicine, R.A.F. Halton, Aylesbury, Bucks. The standard twin-coil costs $£ 21$ and the Chron-a-coil costs $£ 10158$. and 12 acute-on-chronic renal failure. Dialysance studies (see below) were carried out in detail during 14 dialyses. Among the hypercatabolic group of patients 40 Chron-a-coil dialyses were specifically limited to six hours' duration with a bloodflow rate of $300 \mathrm{ml}$./min., which was accurately monitored by an electromagnetic flow-meter (Brennand and Bunker, 1960). Another 40 standard twin-coil dialyses were done on the same group under the same conditions, thus allowing clinical and biochemical comparisons to be made. Plasma urea and creatinine were estimated routinely before and after each dialysis. In addition the priming volume, distensibility, and ultrafiltration characteristics of the Chron-a-coil were measured.

\section{Clinical Results}

Hypercatabolic Patients.-Table I shows the results in eight consecutive patients treated by intensive dialysis. The criterion for selection was four dialyses within the first five days of admission. All the patients were highly catabolic for at least 10 days, and several for longer periods. In every case; once the clinical state had been brought under control in the first 48 hours, the patients were alert and co-operative, and were feeding by mouth. The only patient who died was kept in an excellent clinical state until further gastric bleeding, unrelated to dialysis, and surgical complications caused us to stop treatment. Fifty-nine out of the 122 dialyses were done with Chron-a-coils. The objects of reduced morbidity and prevention of uraemic symptoms were achieved. Figs. 1 and 2 show the effects of dialysis on plasma urea and creatinine respectively. The post-dialysis value is expressed as a percentage of the predialysis value, and in both figures results for standard twin-coil and Chron-a-coil dialyses are shown. All dialyses were done under the standard conditions described previously. With both creatinine and urea there is a clear relation between the predialysis level and the subsequent fall after six hours with each type of coil. There is considerable overlap of post-dialysis plasma urea results, and in the pre-dialysis range of 100 to $200 \mathrm{mg} . / 100 \mathrm{ml}$. (in which we attempted to keep the hypercatabolic patients) there is only about a $10 \%$ difference. A clear separation of results for creatinine with each type of coil is seen in Fig. 2. This is a consequence of the fact that creatinine is less well dialysed than urea. The average plasma creatinine after six hours' dialysis with a Chron-a-coil is about

\begin{tabular}{|c|c|c|c|c|c|c|c|c|}
\hline $\begin{array}{l}\text { Case } \\
\text { No. }\end{array}$ & Sex & Age & Renal Lesion & Associated Conditions & $\begin{array}{c}\text { Duration } \\
\text { of } \\
\text { Oliguria } \\
\text { (days) }\end{array}$ & $\begin{array}{c}\text { Kolff } \\
\text { Twin- } \\
\text { coil } \\
\text { Dialyses }\end{array}$ & $\begin{array}{l}\text { Chron-a- } \\
\text { coil - } \\
\text { Dialyses }\end{array}$ & Results \\
\hline $\begin{array}{l}39 / 65 \\
40 / 65\end{array}$ & $\mathbf{M}$ & $\begin{array}{l}35 \\
35\end{array}$ & $\begin{array}{l}\text { Tubular necrosis } \\
\text { } " \#\end{array}$ & $\begin{array}{l}\text { Traumatic amputation right leg. Dislocation left knee } \\
\text { Fractured pelvis. Crushed left chest, with pneumothorax and haemo- } \\
\text { thorax. Tracheostomy }\end{array}$ & $\begin{array}{l}30 \\
22\end{array}$ & $\begin{array}{r}19 \\
5\end{array}$ & $\mathbf{4}$ & $\begin{array}{l}\text { Recovered } \\
n\end{array}$ \\
\hline 45/65 & $\mathbf{F}$ & 58 & $\begin{array}{l}\text { Tubular necrosis. } \\
\text { Staphylococcal } \\
\text { pyelonephritis }\end{array}$ & $\begin{array}{l}\text { Bleeding gastric ulcer. Staphylococcal septicaemia and staphylococcal } \\
\text { bronchopneumonia. Partial gastrectomy and burst duodenal stump }\end{array}$ & 51 & 6 & 9 & Died \\
\hline $\begin{array}{r}46 / 65 \\
48 / 65 \\
4 / 66 \\
2 / 66\end{array}$ & $\begin{array}{l}M \\
M \\
M \\
M\end{array}$ & $\begin{array}{l}36 \\
18 \\
55 \\
58\end{array}$ & $\begin{array}{l}\text { Tubular necrosis } \\
\text { "\# \#" } \\
\text { Tubular necrosis. } \\
\text { Staphylococcal }\end{array}$ & $\begin{array}{l}\text { Perforated appendix. Pulmonary embolus. Septicaemia } \\
\text { Fractured pelvis. Fractured right femur and right humerus } \\
\text { Thromboendarterectomy of right external iliac and left common iliac } \\
\text { Diabetic ketosis with staphylococcal septicaemia and potassium deple- } \\
\text { tion. Prolonged delay (45 days) in recovery of renal function, despite }\end{array}$ & $\begin{array}{l}24 \\
25 \\
28 \\
10\end{array}$ & $\begin{array}{r}7 \\
14 \\
4 \\
1\end{array}$ & $\begin{array}{l}8 \\
7 \\
3 \\
8\end{array}$ & $\begin{array}{c}\text { Recovered } \\
" \# \\
"\end{array}$ \\
\hline 9/66 & $\mathbf{M}$ & 63 & Tubular necrosis & Crush injuries-fractured pelvis, right pneumothorax & 24 & 7 & 8 & " \\
\hline
\end{tabular}


$65 \%$ of the initial value, and with a standard twin-coil about $50 \%$.

Patients with Severe Uraemia and Acidosis.-No serious neurological or cardiovascular disturbance was seen during any Chron-a-coil dialysis, though many patients were severely uraemic at the time of their first dialysis. Although it cannot be proved that a standard twin-coil dialysis would have produced disequilibrium in any of these patients, experience in the past would have led us to anticipate it. Measures which have been shown to reduce the incidence of dialysis disequilibrium have mainly involved reducing the efficiency of the dialysis, and our results seemed to be in accordance with this concept.

Other Uses of the Chron-a-coil.-The Chron-a-coil was useful in dialysing a 10-month-old infant. Only one coil was used, so the extracorporeal blood volume was reduced to $250 \mathrm{ml}$. Several patients with serious hyperkalaemia were given a quick Chron-a-coil dialysis with only saline priming when there was a delay in obtaining fresh blood.

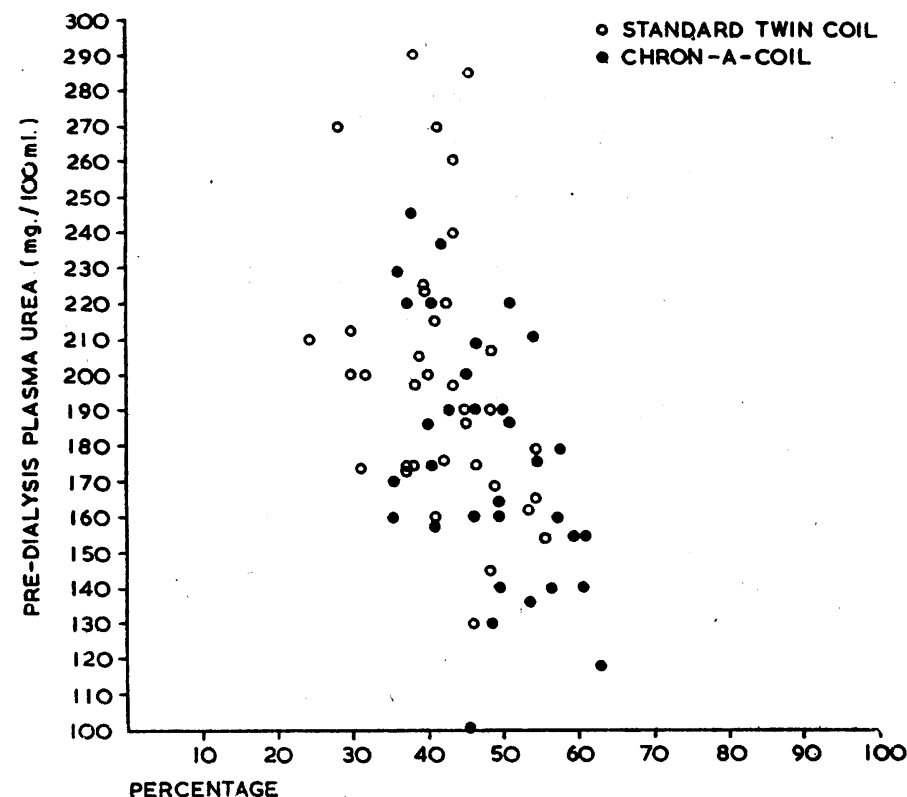

FIG. 1.-Post-dialysis plasma urea as percentage of pre-dialysis vahue (six-hour dialysis).

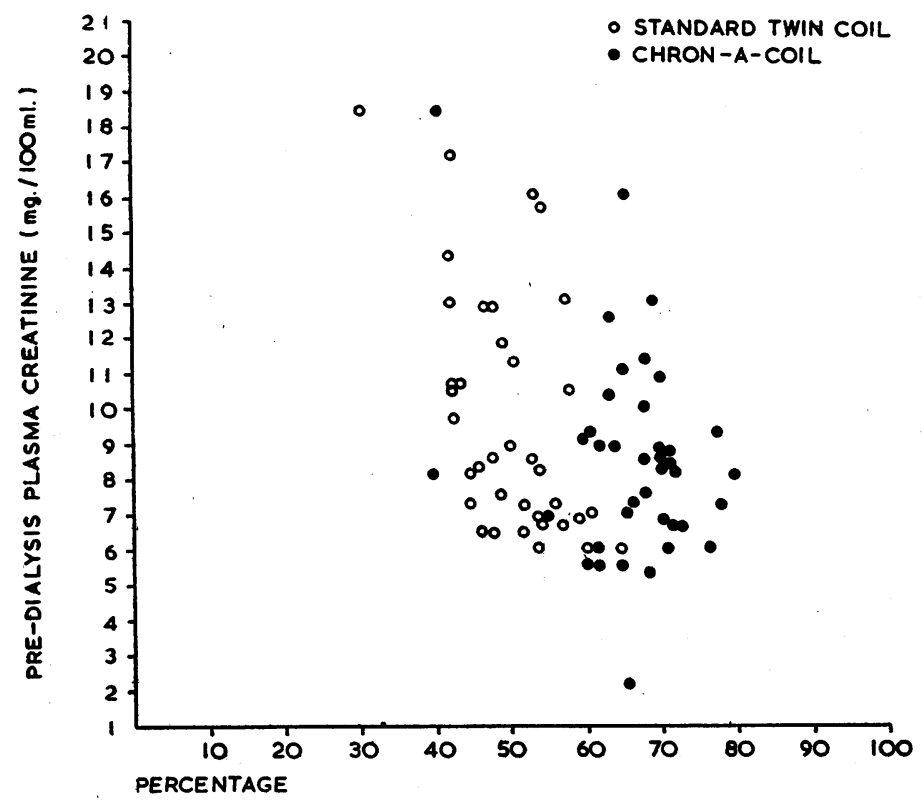

FIG. 2.- Post-dialysis plasma creatinine as percentage of pre-dialysis value (sir-hour dialysis).

\section{Physical Characteristics of the Chron-a-coil}

Priming Volume.-Blood-priming volume was estimated as the volume of blood required to fill the coils and tubing after saline priming. This obviously underestimates the full volume, as there is some dilution of the blood with saline. Nevertheless we were able to make the important practical conclusion that only one bottle of blood is necessary to prime the Chron-a-coil. By pumping air through coils to expel the contents after saline priming we estimated a maximum volume of $600 \mathrm{ml}$. Blood priming was used to avoid the risk of hypotension in all the early dislyses, but with increasing experience the Chron-a-coil was often primed only with saline.

Ultrafiltration.-When it was necessary to remove excess fluid a circuit pressure of $200 \mathrm{~mm}$. $\mathrm{Hg}$ was applied and the dextrose concentration of the dialysing fluid raised to $800 \mathrm{mg}$./ $100 \mathrm{ml}$. The volume of ultrafiltrate, as estimated by weight loss, was between $1 \frac{1}{2}$ and 3 litres in six hours, which is about one-half the volume achieved with the standard twin-coil in the same conditions.

Inelastic Distension of the Coils.-A Chron-a-coil was primed with outdated blood. Another bottle of outdated blood was used as a reservoir, and the ends of the arterial and venous lines were placed in it. Blood was pumped through the system at a flow rate of $300 \mathrm{ml} . / \mathrm{min}$. The circuit pressure was raised from zero to $200 \mathrm{~mm}$. $\mathrm{Hg}$ by a clamp on the venous line. The increase in volume of the coils, as measured by the decrease in volume of the blood reservoir, was 200 to $300 \mathrm{ml}$. When the pressure was reduced back to zero between 100 and $150 \mathrm{ml}$. of blood remained in the coils because of inelastic distension. This would be the anticipated increase in volume if ultrafiltration were applied during dialysis as described above and must be allowed for, particularly if blood is not used for priming. This method was shown to us by Dr. D. N. S. Kerr (personal communication, 1965).

Internal Resistance.-Although the Chron-a-coil had a lower internal resistance than the standard twin-coil blood pumping was still required, as the flow rates achieved were otherwise too low for effective dialysis.

\section{Dialysance Studies}

These were carried out in detail on 14 Chron-a-coil and two standard twin-coil dialyses. Blood samples were taken from the arterial and venous lines simultaneously with a sample of dialysing fluid at 10 minutes, one hour, and two hours. The dialysing fluid was changed every two hours and the sampling repeated, so that nine sets of samples were available for each dialysis of six hours. Blood-flow rates were accurately measured by an electromagnetic flow-meter, thus avoiding criticism which has been made of many dialysance studies (Sweeney and Galletti, 1964). Dialysance was calculated from the formula :

$$
\text { Dialysance }(D)=\frac{A-V}{A-B} \times F
$$

Where $\mathrm{A}=$ arterial concentration, $\mathrm{V}=$ venous concentration, $\mathbf{B}=$ dialysing-fluid concentration, $\mathbf{F}=$ blood-flow rate.

A total of 150 measurements of the dialysance were made. Table II shows the mean results of the determinations and the observed range of the results.

For comparison we give the results of Freeman et al. (1964), who made in vitro dialysance determinations, and of Versaci et al. (1964), who made in vivo clearance studies. The results were interpolated from their graphs of dialysance or clearance against blood-flow rate. There is close agreement between our results and those of Freeman et al. The rather wide range of results shows that there is appreciable variation in dialysance between different coils, but individual coils varied 
little during a six-hour period. The Chron-a-coil can be seen to have a dialysance of 60 to $70 \%$ of that of the standard twincoil. Urea estimations were made on the AutoAnalyzer by the method of Rigby and Hull (1964), and creatinine by the Technicon standard method modified to increase sample volume uptake.

TABLE II.-Mean Dialysance at Blood-flow Rate $300 \mathrm{ml} . / \mathrm{min}$.

\begin{tabular}{|c|c|c|c|c|}
\hline Type of Coil & Authors & $\begin{array}{l}\text { No. of Twin- } \\
\text { coils Tested }\end{array}$ & $\begin{array}{c}\text { Urea } \\
\text { (mg./100 ml.) }\end{array}$ & $\begin{array}{c}\text { Creatinine } \\
\text { (mg./100 ml.) }\end{array}$ \\
\hline $\begin{array}{c}\text { Chron-a-coil } \\
\text { ", }\end{array}$ & $\begin{array}{l}\text { Freeman et al. } \\
\text { Versaci et al. } \\
\text { Present series }\end{array}$ & $\begin{array}{r}-8 \\
14\end{array}$ & $\begin{array}{c}100 \text { (90-105) } \\
76 \text { (clearance) } \\
96 \text { (64-117) } \\
\text { (mean of } 150\end{array}$ & $\begin{array}{l}65(50-75) \\
69(51-88)\end{array}$ \\
\hline $\begin{array}{c}\text { Standard } \\
, \\
,\end{array}$ & $\begin{array}{l}\text { Freeman et al. } \\
\text { Versaci et al. } \\
\text { Present series }\end{array}$ & $\overline{12}$ & $\begin{array}{c}160(125-175) \\
165 \text { (clearance) } \\
168\end{array}$ & $\frac{120(75-150)}{110}$ \\
\hline
\end{tabular}

\section{Discussion}

The value of dialysis in acute renal failure is now beyond doubt, and there is general agreement that the best results are obtained if the patient is transferred to a special unit as soon as the diagnosis is established. There is much less agreement on the best form of dialysis and the frequency with which it is used. The tendency in most units has been to simplify techniques and to dialyse more often. The reduced morbidity which is a result of more frequent dialysis helps to sustain patients through what is often a long and always unpleasant illness. Conclusions regarding improved mortality rates are probably not justified because of the variable influences of age, pre-existing renal disease, and associated injuries and diseases. One point does merit emphasis, however-namely, that if complications related to the primary disease occur, diagnosis is easier and treatment more effective if the patient has been kept relatively non-uraemic.

There is a need for flexibility in choosing an artificial kidney most appropriate to the needs of different patients, and for individual patients at different periods of their illness (Cosbie Ross et al., 1966). It matters less what types are available than that a choice exists. Our conclusion from this study is that the Chron-a-coil provides a valuable alternative choice in any unit already using Kolff twin-coil haemodialysis in the treatment of acute renal failure. It has the advantage that no new equipment or change in technique is necessary.

From our experience to date we are able to suggest the following indications for using a Chron-a-coil in acute renal failure:

1. In the first dialysis of all severely uraemic patients, extending the duration of the dialysis to 12 hours if necessary. We believe this to be safer and more effective than a standard twin-coil dialysis of six hours' duration.

2. In the daily dialysis of hypercatabolic patients with serious associated conditions, once the clinical condition has been stabilized by as many standard-coil dialyses as necessary. In such circumstances it is often possible to dispense with blood priming, and a considerable saving of coil cost and blood is achieved.

3. In children and very small adults for whom it is desirable to keep an extracorporeal blood volume during dialysis proportionately small.

4. When urgent dialysis is required for hyperkalaemia and fresh blood is not immediately available. The risk of priming the coils with saline only may be less than when waiting for blood.

5. In the occasional dialysis of patients who are not. hypercatabolic but who have a prolonged oliguric phase. The indication here is relative and depends upon the work load. Circumstances permitting, we would prefer, for example, to dialyse such patients five times with a Chron-a-coil than three times with a standard twin-coil.

Finally, a note of caution about reliance on plasma urea levels is necessary. As reported by Ashcroft et al. (1964), plasma urea is not the best index of clinical uraemia, and is even less reliable after repeated haemodialysis, which removes urea preferentially to other nitrogenous-retention products such as creatinine or uric acid. This preferential clearance of urea compared with creatinine is clearly seen from Figs. 1 and 2 . These differences may be further accentuated if the patient is kept on a lowprotein diet. In choosing between Chron-a-coil and a standard twin-coil some discrimination is therefore necessary and careful appraisal of the clinical state,' dietary protein intake, and creatinine and uric acid levels will be more reliable than plasma urea alone.

\section{Summary}

The Chron-a-coil is a smaller version of the Kolff twin-coil artificial kidney and is used with the same apparatus. The cost and the blood required for priming are about one-half those of the standard twin-coil. Chron-a-coils were used to perform 120 haemodialyses in the treatment of 30 patients with acute renal failure, and as a result the following indications were formulated: (1) to reduce the cost and blood-usage of prophylactic daily dialysis, (2) for the slow dialysis of seriously ill patients, (3) for the dialysis of children and very small adults, and (4) when urgent dialysis is required and blood is not available.

The blood-priming volume of -the Chron-a-coil was 400 to $500 \mathrm{ml}$., but priming only with saline was often possible if the patient was in good condition. Average ultrafiltration of $\mathbf{3 0 0}$ $\mathrm{ml}$./hour was found possible. The urea dialysance was studied in detail on 14 Chron-a-coils and was found to be 60 to $70 \%$ that of the standard twin-coil. Urea was found to be dialysed preferentially to creatinine, and the significance of this is mentioned. It is concluded that the Chron-a-coil has a definite place in the management of patients with acute renal failure.

We thank Air Commodore W. P. Stamm, senior consultant in pathology and tropical medicine, and Wing Commander T. C. Nicol, consultant in medicine, for their interest in this work, and Flight Lieutenant E. Anderson, who assisted in treatment of the patients. We gratefully acknowledge the skilled technical assistance of Corporal H. S. Akerman and Corporal P. Attoe. We are indebted to Baxter Laboratories Limited for the supply of the Chron-a-coils used in the trial. We wish to thank the Director-General of Medical Services, Royal Air Force, for permission to publish.

\section{REFERENCES}

Ashcroft, R., Clarkson, B. A., Elliot, R. W., Horn, D. B., Kerr, D. N. S., and Robson, A. M. (1964). Proceedings European Dialysis and Transplant Association, 1, 297.

Brennand, R., and Bunker, N. V. D. (1960). Lancet, 1, 578

Cosbie Ross, J., Edwards, E. G., and Goldsmith, H. J. (1966). Practitioner, 196, 128.

Cowie, J., Lambie, A. T., and Robson, J. S. (1962). Clin. Sci., 23, 397. Freeman, R. B., Setter, J. G., Maher, J. F., and Schreiner, G. E. (1964). Trans. Amer. Soc. artif. intern. organs, $10,174$.

Jackson, R. C., Bunker, N. V. D., Elder, W. J., and Joekes, A. M. (1960). Brit. med. F., 2, 1909.

Kennedy, A. C., Linton, A. L., and Eaton, J. C. (1962). Lancet, 1, 410. Merrill, J. P. (1963). Diseases of the Kidney, edited by M. B. Strauss and L. G. Welt, p. 220. Little, Brown, Boston.

Rigby, C. J., and Hull, N. J. (1964). Proc. Ass. clin. Biochem. 3, 17.

Sweeney, M. J., and Galletti, P. M. (1964). Trans. Amer. Soc. artif. intern. organs, $10,3$.

Teschan, P. E., Baxter, C. R., O'Brien, T. F., Freyof, J. N., and Hall, W. H. (1960). Ann. intern. Med., 53, 992

Versaci, A. A., Nakamoto, S., and Kolff, W. J. (1964). Trans. Amer. Soc. artif. intern. organs, $10,196$. 